\title{
Diversity of metazoan parasites in fish Triportheus angulatus and Triportheus auritus living in sympatry in the Brazilian Amazon
}

\author{
Diversidade de parasitos metazoários em peixes Triportheus angulatus e \\ Triportheus auritus vivendo em simpatria na Amazônia brasileira \\ William Felix Borges ${ }^{1}$ (D); Marcos Sidney Brito Oliveira ${ }^{1}$ (i); Marcos Tavares-Dias ${ }^{1,2 \star}$ (1)
}

1 Programa de Pós-graduação em Biodiversidade Tropical - PPGBio, Universidade Federal do Amapá - UNIFAP, Macapá, AP, Brasil ${ }^{2}$ Embrapa Amapá, Macapá, AP, Brasil

How to cite: Borges WF, Oliveira MSB, Tavares-Dias M. Diversity of metazoan parasites in fish Triportheus angulatus and Triportheus auritus living in sympatry in the Brazilian Amazon. Braz J Vet Parasito/ 2021; 30(3): e008221. https://doi.org/10.1590/ S1984-29612021064

\begin{abstract}
The aim of this study was to compare the diversity and community structure of metazoan parasites in sympatric populations of Triportheus angulatus and Triportheus auritus in the Jari River basin, in the eastern Brazilian Amazon. All the specimens of $T$. angulatus and $T$. auritus examined were infected by Anacanthorus furculus, Anacanthorus pithophallus, Digenea gen. sp., Procamallanus (Spirocamallanus) inopinatus, Rhabdochona acuminata, Contracaecum sp., Ergasilus sp. and Acarina gen. sp. These parasites displayed aggregated or random dispersion. The parasite community in T. angulatus and T. auritus presented a similarity of $78 \%$. The diversity indice and richness of parasite species were greater in T. auritus and there were differences in levels of host parasite infection for some infracommunities. Phyllodistomum spatula occurred only in T. angulatus, while metacercariae of Clinostomum marginatum and Digenea gen. sp.2 occurred only in T. auritus. The species richness of the parasites was influenced by host size, as well as the abundance of some parasite infracommunities. This is the first report of these parasites for $T$. angulatus and T. auritus, except for $P$. (S.) inopinatus and Contracaecum sp. for T. angulatus.
\end{abstract}

Keywords: Amazon, community, fish, helminth, parasites, similarity.

\section{Resumo}

O objetivo deste estudo foi comparar a diversidade e comunidade de parasitos metazoários em populações simpátricas de Triportheus angulatus e Triportheus auritus da bacia do Rio Jari, na Amazônia oriental brasileira. Todos os espécimes de T. angulatus e $T$. auritus examinados estavam infectados por Anacanthorus furculus, Anacanthorus pithophallus, Digenea gen. sp., Procamallanus (Spirocamallanus) inopinatus, Rhabdochona acuminata, Contracaecum sp., Ergasilus sp. e Acarina gen. sp. Esses parasitos apresentaram dispersão agregada ou randômica. A comunidade de parasitos em $T$. angulatus e $T$. auritus apresentou uma similaridade de $78 \%$. A diversidade e riqueza de espécies de parasitos foram maiores em $T$. auritus e houve diferenças nos níveis de infecção parasitária entre os hospedeiros para algumas infracomunidades. Phyllodistomum spatula ocorreu somente em T. angulatus, enquanto metacercárias de Clinostomum marginatum e Digenea gen. sp.2 ocorreram somente em T. auritus. A riqueza de espécies de parasitos foi influenciada pelo tamanho dos hospedeiros, bem como pela abundância de algumas infracomunidades de parasitos. Este é o primeiro relato desses parasitos para $T$. angulatus e $T$. auritus, exceto $P$. (S.) inopinatus e Contracaecum sp. para T. angulatus.

Palavras-chave: Amazônia, comunidade, peixe, helminto, parasito, similaridade. 


\section{Introduction}

The Jari River basin is located in the division between the south of the state of Amapá and the north of the state of Pará, in the north of Brazil. Its source is found in the Serra do Tumucumaque mountain range on the border between Brazil and French Guiana, and it is approximately $800 \mathrm{~km}$ long, with its mouth on the Amazon River to the south of the state of Amapá. It has a clear water basin system, and the region is comprised of tropical rainforest (EPE, 2010). There is the presence of anthropic action in the south of the basin, where the original forest was replaced by agricultural activities and silvicultural explorations (Cunha \& Cunha, 2010; Abreu \& Cunha, 2015). In addition, the region has a great diversity of birds, zooplankton and several other invertebrates that form part of the diet of fish, and which can be hosts for different species of fish parasites.

Triportheus are freshwater fish of the Triportheidae family and Characiformes order, which contains 19 valid species (Froese \& Pauly, 2021), including Triportheus angulatus (Spix \& Agassiz, 1829) and Triportheus auritus (Valenciennes, 1850). Triportheus angulatus is distributed in the Amazon and Essequibo River basins, while T. auritus is more widely distributed, and is found in the Amazon, Essequibo, Tocantins, and Araguaia river basins, and on the Ilha de Trindade (Trindade Island) (Lima et al., 2003; Lasso \& Sánchez-Duarte, 2011; Malabarba, 2004; Froese \& Pauly, 2021). Both species are benthopelagic and have omnivorous feeding habits, feeding mainly on insects, fruits, seeds, fragments of fish, plankton and crustaceans (Almeida, 1984; Yamamoto et al., 2004; Lasso \& Sánchez-Duarte, 2011; Sá-Oliveira et al., 2014; Rojas et al., 2016; Froese \& Pauly, 2021). In general, the reproduction of these fish occurs in the rainy season, when there are lateral migrations to floodplain areas (Santos et al., 1984; Soares et al., 2011; Lasso \& Sánchez-Duarte, 2011; Araújo et al., 2012), a favorable environment for fish larvae feeding. As such, in general, T. angulatus and T. auritus are caught in schools in rivers and flooded forests (Lasso \& Sánchez-Duarte, 2011; Sá-Oliveira et al., 2014). Triportheus angulatus and T. auritus (Ponte et al., 2016; Goulding et al., 2018) are consumed in the Amazon basin, and are species whose biology has been little studied, notably their parasite diversity and communities.

In wild fish populations, studies on parasite fauna are important not only for understanding diversity, biogeography and population distribution, but also parasite-host-environment interactions (Tavares-Dias et al., 2014; Oliveira et al., 2016; Moreira et al., 2017; Baia et al., 2018). In several species of fish in the Amazon Basin, an ecosystem that serves as a habitat for a number of parasite species, parasite community and infracommunities are yet to be studied, and include species of hosts living in the same environment (sympatry), which tend to have similar parasite communities and infracommunities (Muñoz et al., 2006; Oliveira et al., 2016; Hoshino et al., 2016; Santos-Bustos et al., 2018). However, the community and infracommunities of parasites of sympatric populations of $T$. angulatus and $T$. auritus have not yet been investigated. As such, the aim of the present study was to compare the diversity and community structure of metazoan parasites of $T$. angulatus and $T$. auritus living in sympatry in the Jari River basin, in the eastern Brazilian Amazon.

\section{Material and Methods}

\section{Study area and collection of fishes}

Twice monthly, from January to July 2020, T. angulatus and T. auritus were collected in river and stream bank areas and lowland regions of the lower Jari River, close to the Jarilândia District, in the municipal region of Vitória do Jari, in the state of Amapá, Brazil (Figure 1). Fish were collected using reeds, hand lines, nets and gillnets with $25 \mathrm{~mm}$ and $30 \mathrm{~mm}$ meshes.

The collection of fish was authorized by the Brazilian Ministry of the Environment (SISBio No 73550-1). This study was developed in accordance with the principles adopted by the Brazilian College of Animal Experimentation (COBEA) and was conducted under authorization from the Ethics Committee for Animal Use of Embrapa Amapá (Protocol No 014/2018).

\section{Parasite collection and analysis procedures}

Each fish was weighed $(\mathrm{g})$ and measured (standard length, $\mathrm{cm}$ ), before being necropsied for parasitological analysis. The body surface, opercula, gastrointestinal tract and viscera were examined at the collection site, while the gills were fixed in heated $5 \%$ formalin $\left(60-70^{\circ} \mathrm{C}\right)$ and analyzed at the Embrapa Amapá Aquaculture and Fisheries Laboratory, Macapá (Brazil). The mouth, gills, opercula and fins were examined to check for the presence of 


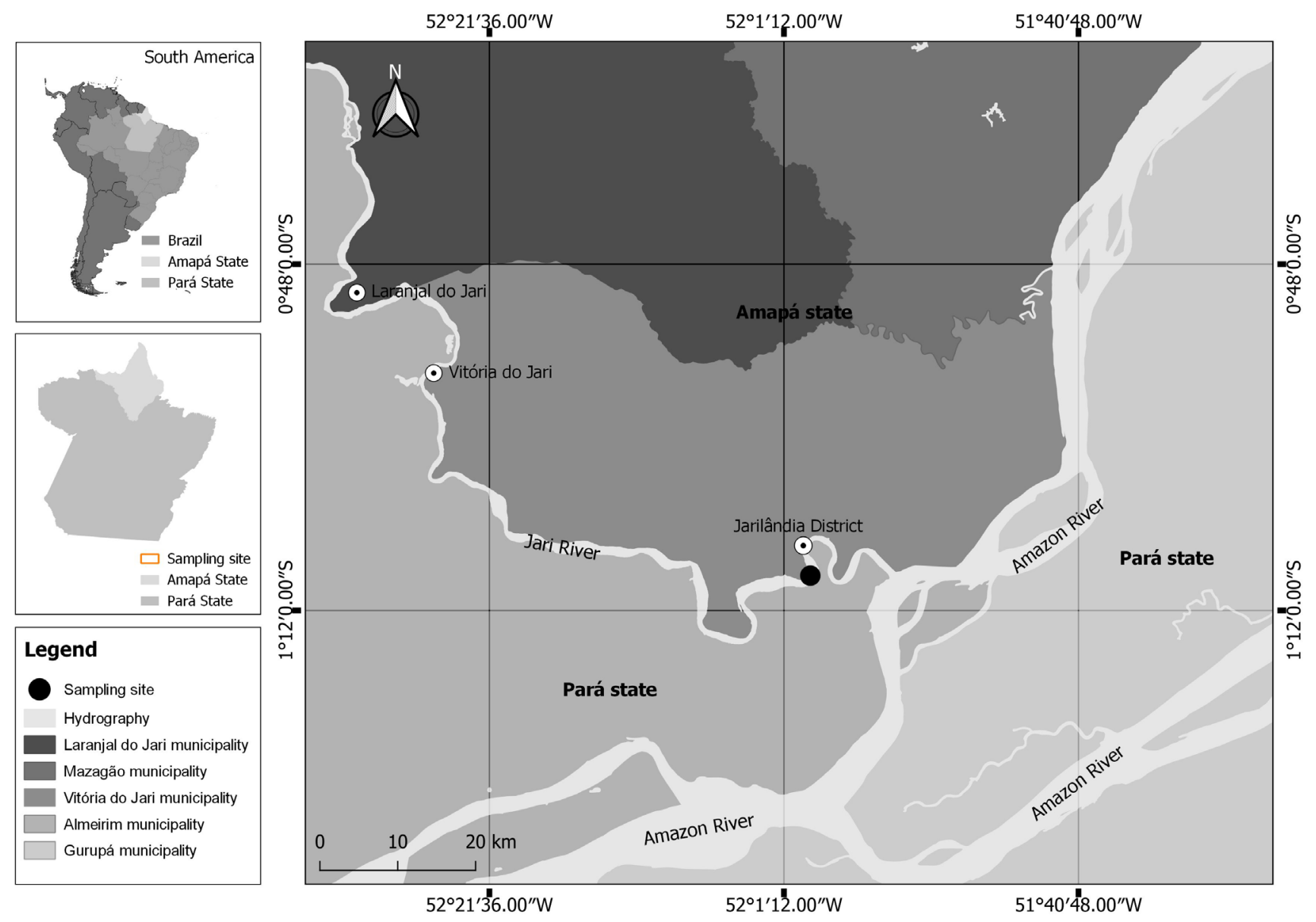

Figure 1. Collection site of Triportheus angulatus and Triportheus auritus in lower Jari River, in Amazon River system (Brazil).

ectoparasites and the viscera and gastrointestinal tract for the presence of endoparasites. The collection, fixation, conservation and preparation of the parasites for identification followed previous recommendations (Eiras et al., 2006). The ecological terms used were those recommended by Bush et al. (1997).

\section{Statistical analyses}

The normality and homoscedasticity of the data were evaluated using the Shapiro-Wilk and Bartlett tests, respectively. The Brillouin index (HB), Uniformity, Berger-Parker dominance index, species richness (Magurran, 2004) and frequency of dominance, that is, the percentage of infracommunities in which a given parasite species is numerically dominant (Rohde et al., 1995), were calculated to assess the parasite component community using Diversity software (Pisces Conservation Ltd, UK). For comparison of prevalence between T. angulatus and T. auritus the chi-square test $\left(\chi^{2}\right)$ was used, followed by Yates's correction. The mean intensity, mean abundance, species richness, diversity index, evenness and Berger-Parker dominance between both hosts were compared with the Mann-Whitney (U) test (Zar, 2010).

The dispersion index (DI) and discrepancy index (D) of Poulin were calculated using the Quantitative Parasitology 3.0 software package, to detect the distribution patterns of the parasite infracommunities (Rózsa et al., 2000) for species with prevalence $>10 \%$. The significance of the DI, for each infracommunity, was tested using the d-statistic test (Ludwig \& Reynolds, 1988).

Using the R software package (R Core Team, 2020), Non-metric Multidimensional Scaling (NMDS) was performed to order the parasite abundance data from the similarity matrix generated through the Bray-Curtis quantitative index. To test the differences between the parasite component communities of $T$. angulatus and $T$. auritus, the ANOSIM test was used with 999 permutations using the Jaccard (J) similarity index (presence/absence of species), 
and Bray-Curtis dissimilarity index (B) (abundance). The Similarity Percentage test (SIMPER) was used to detect the contribution of each parasite species in the sampling.

The body weight $(\mathrm{W})$ and the total length $(\mathrm{L})$ data were used to calculate the relative condition factor $(\mathrm{Kn})$ of the host fish, as well as the length-weight relationship $\left(W=a L^{b}\right)$ after the logarithmic transformation of the length $(L)$ and weight (W) and subsequent adjustment of two straight lines, thereby obtaining $\ln y=\ln a+b \ln L$ (Le Cren, 1951).

The Spearman correlation coefficient ( $r s$ ) was used to determine possible correlations of the abundance of parasites with the length, weight and Kn of hosts, as well as of hosts length with the species richness and HB.

\section{Results}

All specimens of $T$. angulatus and T. auritus examined (100\%) were infected with one or more species of parasites, and a total of 2,410 parasites were collected. Both the hosts were parasitized by Anacanthorus furculus (Kritsky, Boeger \& Van Every, 1992), Anacanthorus pithophallus (Kritsky, Boeger \& Van Every, 1992), Digenea gen. sp.1; Procamallanus (Spirocamallanus) inopinatus (Travassos, Artigas \& Pereira, 1928), Rhabdochona acuminata (Molin, 1860), Contracaecum sp., Ergasilus sp. e Acarina gen.sp. However, Phyllodistomum spatula (Odhner, 1902) occurred only in T. angulatus, while the metacercariae of Clinostomum marginatum (Rudolphi, 1819) and Digenea gen. sp.2 occurred only in $T$. auritus. However, in both hosts, the monogeneans A. furculus and A. pithophallus were dominant (Table 1).

Table 1. Parasites in Triportheus spp. from lower Jari River, in Brazilian Amazon.

\begin{tabular}{|c|c|c|c|c|c|c|c|c|c|c|c|c|}
\hline \multirow[b]{2}{*}{ Parasite species } & \multicolumn{6}{|c|}{ Triportheus angulatus $(\mathrm{n}=30)$} & \multicolumn{6}{|c|}{ Triportheus auritus $(\mathrm{n}=34)$} \\
\hline & $\mathbf{P}(\%)$ & MI & MA & TNP & FD (\%) & SI & $\mathbf{P}(\%)$ & MI & MA & TNP & $\begin{array}{l}\text { FD } \\
(\%)\end{array}$ & SI \\
\hline $\begin{array}{l}\text { Anacanthorus furculus } \\
\text { and Anacanthorus } \\
\text { pithophallus }\end{array}$ & 96.7 & $37.4 \pm 41.8$ & $36.2 \pm 41.7$ & 1085 & 77.1 & Gills & 97.1 & $16.9 \pm 17.2$ & $16.4 \pm 17.5$ & 558 & 55.7 & Gills \\
\hline $\begin{array}{l}\text { Digenea gen. sp.1 } \\
\text { (metacercariae) }\end{array}$ & 20.0 & $1.8 \pm 0.5$ & $0.4 \pm 0.9$ & 11 & 0.8 & Gills & 23.53 & $1.3 \pm 0.3$ & $0.3 \pm 0.6$ & 10 & 1.0 & Gills \\
\hline $\begin{array}{l}\text { Phyllodistomum } \\
\text { spatula } \\
\text { (metacercariae) }\end{array}$ & 30.0 & $6.6 \pm 2.1$ & $2.0 \pm 5.5$ & 59 & 4.2 & $\begin{array}{l}\text { Swim } \\
\text { bladder }\end{array}$ & - & - & - & - & - & - \\
\hline $\begin{array}{l}\text { Digenea gen. sp.2 } \\
\text { (metacercariae) }\end{array}$ & 3.33 & $1.0 \pm 0.2$ & 0.0 & 1 & 0.07 & Liver & - & - & - & - & - & - \\
\hline $\begin{array}{l}\text { Clinostomum } \\
\text { marginatum } \\
\text { (metacercariae) }\end{array}$ & - & - & - & - & - & - & 5.88 & $1.5 \pm 0.2$ & $0.1 \pm 0.4$ & 3 & 0.3 & Muscle \\
\hline $\begin{array}{l}\text { Digenea gen. sp.2 } \\
\text { (metacercariae) }\end{array}$ & - & - & - & - & - & - & 17.65 & $1.0 \pm 0.1$ & $0.2 \pm 0.4$ & 6 & 2.1 & Intestine \\
\hline $\begin{array}{l}\text { Procamallanus (S.) } \\
\text { inopinatus }\end{array}$ & 53.3 & $1.9 \pm 0.8$ & $1.0 \pm 1.1$ & 31 & 2.2 & $\begin{array}{l}\text { Pyloric } \\
\text { caeca }\end{array}$ & 44.12 & $1.7 \pm 0.8$ & $0.7 \pm 1.0$ & 25 & 2.5 & $\begin{array}{l}\text { Pyloric } \\
\text { caeca }\end{array}$ \\
\hline $\begin{array}{l}\text { Procamallanus (S.) } \\
\text { inopinatus }\end{array}$ & 20.0 & $2.2 \pm 0.7$ & $0.4 \pm 1.5$ & 13 & 0.9 & Intestine & 38.24 & $1.8 \pm 1.1$ & $0.7 \pm 1.3$ & 24 & 2.4 & Intestine \\
\hline $\begin{array}{l}\text { Rhabdochona } \\
\text { acuminata }\end{array}$ & 3.33 & $108.0 \pm 1.1$ & $3.6 \pm 19.7$ & 108 & 7.7 & $\begin{array}{l}\text { Caecum } \\
\text { pyloric }\end{array}$ & 8.82 & $2.7 \pm 0.7$ & $0.2 \pm 0.9$ & 8 & 0.8 & $\begin{array}{l}\text { Caecum } \\
\text { pyloric }\end{array}$ \\
\hline $\begin{array}{l}\text { Rhabdochona } \\
\text { acuminata }\end{array}$ & 3.33 & $37.0 \pm 2.1$ & $1.2 \pm 6.8$ & 37 & 2.6 & Intestine & 23.53 & $31.0 \pm 14.1$ & $7.3 \pm 19.1$ & 248 & 24.7 & Intestine \\
\hline $\begin{array}{l}\text { Contracaecum sp. } \\
\text { (larvae) }\end{array}$ & 43.3 & $2.6 \pm 0.8$ & $1.1 \pm 2.4$ & 34 & 2.4 & $\begin{array}{l}\text { Abdominal } \\
\text { cavity }\end{array}$ & 41.18 & $3.1 \pm 2.0$ & $1.3 \pm 3.0$ & 44 & 4.4 & $\begin{array}{l}\text { Abdominal } \\
\text { cavity }\end{array}$ \\
\hline Ergasilus sp. & 6.7 & $1.5 \pm 0.6$ & $0.1 \pm 0.4$ & 3 & 0.2 & Gills & 58.82 & $2.8 \pm 1.2$ & $1.6 \pm 2.2$ & 55 & 5.5 & Gills \\
\hline Acarina gen. sp & 26.7 & $3.3 \pm 1.3$ & $0.9 \pm 2.2$ & 26 & 1.8 & Gills & 17.65 & $3.5 \pm 0.8$ & $0.6 \pm 1.8$ & 21 & 2.1 & Gills \\
\hline
\end{tabular}

Abbreviations: $\mathrm{P}$, prevalence; $\mathrm{Ml}$, mean intensity; MA, mean abundance; TNP, total number of parasites; SI, site of infection. FD: Frequency of dominance, SI: Site of infection, $\mathrm{n}=$ Sampling number 
Anacanthorus furculus and A. pithophallus, R. acuminata, Ergasilus sp. and Acarina gen. sp. exhibited aggregate dispersion, while Digenea gen. sp.1 and Digenea gen. sp.2, P. spatula, P. (S.) inopinatus and Contracaecum sp. presented random dispersion (Table 2).

The prevalence of $A$. furculus and $A$. pithophallus was similar $\left(\chi^{2}=0.008, p=0.529\right)$ for $T$. auritus and $T$. angulatus, however the average abundance $(U=327.0, p=0.014)$ and average intensity $(U=293.5, p=0.001)$ were higher in $T$. angulatus. The prevalence $\left(\chi^{2}=0.116, p=0.969\right)$, mean abundance $(U=500.5, p=0.898)$ and mean intensity $(U=15.5, p=0.272)$ of Digenea gen. sp.1 were similar in both hosts. The prevalence $\left(\chi^{2}=0.542, p=0.627\right)$, mean abundance $(U=439, p=0.339)$ and mean intensity $(U=96.0, p=0.343)$ of $P$. (S.) inopinatus were similar in intestine of both hosts. The prevalence $\left(\chi^{2}=2.539, p=0.187\right)$, mean abundance $(U=413.5, p=0.194)$ and mean intensity $(U=35.5, p=0.759)$ of $P$. (S.) inopinatus were similar in pyloric caeca of both hosts. In the pyloric caeca, the prevalence $\left(\chi^{2}=0.820, p=0.698\right)$ and mean abundance $(U=483.5, p=0.721)$ of $R$. acuminata were similar in both hosts. In the intestine, the prevalence $\left(\chi^{2}=5.379, \mathrm{p}=0.05\right)$ of $R$. acuminata was higher in T. auritus than in $T$. angulatus, while the mean abundance $(U=483.5, p=0.0 .721)$ was similar for both hosts. The prevalence $\left(\chi^{2}=0.597, p=0.595\right)$, mean abundance $(U=509.0, p=0.989)$ and mean intensity $(U=81.0, p=0.627)$ of Contracaecum sp. were similar in both hosts. The prevalence $\left(\chi^{2}=19.219, p=0.0001\right)$ and mean abundance $(U=237.5, p=0.0002)$ of Ergasilus sp. were higher in $T$. auritus than $T$. angulatus. The prevalence $\left(X^{2}=0.759, p=0.570\right)$, mean abundance $(U=466.0, p=0.553)$ and mean intensity $(U=22.0, p=0.796)$ of acari were similar in both hosts.

The component community of $T$. angulatus and $T$. auritus was similar and was composed of a similar presence of ectoparasites and endoparasites (Table 3). In T. angulatus, there was a predominance of hosts infected by 2 to 4 parasite species, while in $T$. auritus there was a predominance of hosts infected by 3 to 4 parasite species (Figure 2).

Berger-Parker dominance was greater $(p<0.05)$ in $T$. angulatus, while the Brillouin diversity index, equitability and richness of the parasite species were greater $(p<0.001)$ in $T$. auritus (Figure 3 ).

The NMDS did not reveal differences in parasite abundance between $T$. angulatus and $T$. auritus, with a stress value of 0.022 (Figure 4). The similarity of the component communities of the host populations exhibited qualitative similarity, according to the Jaccard index $(\mathrm{N}=0.78)$ and quantitative dissimilarity according to Bray-Curtis index homogeneity $(B=0.69)$. ANOSIM did not detect any difference between sites but detected a difference between the parasite communities $\left(R_{\text {Jaccard }}=0.169, p=0.0001 ; R_{\text {Bray-Curtis }}=0.049 ; p=0.033\right)$. SIMPER showed that the monogeneans (60.1\%) and $R$. acuminata (15.2\%) contributed most to these differences.

In T. angulatus, Brillouin diversity did not reveal a correlation $\left(r_{s}=-0.235, \mathrm{p}=0.210\right)$ with host length, but the richness of the parasite species correlated negatively $\left(r_{s}=-0.436,0.016\right)$ with host length. In $T$. auritus, Brillouin diversity revealed no correlation $\left(r_{s}=-0.312, p=0.072\right)$ with host length, but the richness of the parasite species correlated positively $\left(r_{s}=0.335, \mathrm{p}=0.053\right)$ with host length. In addition, some parasite infracommunities showed a correlation with the length, weight and Kn of the hosts (Table 4).

Table 2. Dispersion index (DI), $d$-statistic (d) and discrepancy index (D) for infracommunities of parasites in Triportheus spp. from lower Jari River, in Brazilian Amazon.

\begin{tabular}{|c|c|c|c|c|c|c|}
\hline \multirow{2}{*}{$\begin{array}{c}\text { Hosts } \\
\text { Parasite species }\end{array}$} & \multicolumn{3}{|c|}{ Triportheus angulatus } & \multicolumn{3}{|c|}{ Triportheus auritus } \\
\hline & ID & $d$ & D & ID & $d$ & D \\
\hline $\begin{array}{l}\text { Anacanthorus furculus and Anacanthorus } \\
\text { pithophallus }\end{array}$ & 2.270 & 3.289 & 0.343 & 2.100 & 3.587 & 0.351 \\
\hline Digenea gen. sp.1 & 1.410 & 0.858 & 0.806 & 0.990 & -0.102 & 0.765 \\
\hline Digenea gen. sp.2 & - & - & - & 0.850 & -0.673 & 0.800 \\
\hline Phyllodistomum spatula & 1.650 & 1.597 & 0.746 & - & - & - \\
\hline Procamallanus (S.) inopinatus & 1.100 & -0.198 & 0.491 & 1.110 & 0.370 & 0.451 \\
\hline Rhabdochona acuminata & - & - & - & 2.950 & 5.768 & 0.815 \\
\hline Contracaecum sp. & 1.590 & 1.418 & 0.669 & 1.510 & 1.798 & 0.669 \\
\hline Ergasilus sp. & - & - & - & 5.290 & 10.500 & 0.438 \\
\hline Acarina gen. sp. & 2.030 & 2.665 & 0.785 & 2.380 & 4.348 & 0.846 \\
\hline
\end{tabular}


Table 3. Component community of parasites in Triportheus spp. from lower Jari River, in Brazilian Amazon.

\begin{tabular}{ccc}
\hline Characteristics & Triportheus angulatus & Triportheus auritus \\
\hline Examined fish number & 30 & 34 \\
Body length (cm) & $15.2 \pm 2.0$ & $14.3 \pm 2.4$ \\
Weigth (g) & $68.3 \pm 22.2$ & $38.3 \pm 30.4$ \\
Prevalence (\%) of parasites & 100 & 100 \\
Total number of parasites & 1408 & 1002 \\
Ectoparasite species & 5 & 5 \\
Percentage of ectoparasites & 79.9 & 64.3 \\
Endoparasite species & 5 & 5 \\
Percentage of endoparasites & 20.1 & 35.7 \\
Endoparasite species (adults) & 5 & 6 \\
Endoparasite species (larvae) & 4 & 3 \\
\hline
\end{tabular}

Table 4. Spearman correlation coefficient ( $r s$ ) of the abundance of parasites with the total length, body weight and condition factor (Kn) of Triportheus spp. from lower Jari River, in Brazilian Amazon.

\begin{tabular}{|c|c|c|c|c|c|c|c|c|c|c|c|c|}
\hline \multirow{3}{*}{$\begin{array}{c}\text { Hosts } \\
\text { Parasite species }\end{array}$} & \multicolumn{6}{|c|}{ Triportheus angulatus } & \multicolumn{6}{|c|}{ Triportheus auritus } \\
\hline & \multicolumn{2}{|c|}{ Length } & \multicolumn{2}{|c|}{ Weight } & \multicolumn{2}{|c|}{ Kn } & \multicolumn{2}{|c|}{ Length } & \multicolumn{2}{|c|}{ Weight } & \multicolumn{2}{|c|}{ Kn } \\
\hline & $r_{s}$ & $p$ & $r_{s}$ & $p$ & $r_{s}$ & $p$ & $r_{s}$ & $p$ & $r_{s}$ & $p$ & $r_{s}$ & $p$ \\
\hline $\begin{array}{l}\text { Anacanthorus } \\
\text { furculus and } \\
\text { Anacanthorus } \\
\text { pithophallus }\end{array}$ & -0.349 & 0.050 & -0.21 & 0.241 & 0.336 & 0.069 & 0.328 & 0.050 & 0.340 & 0.048 & 0.003 & 0.984 \\
\hline Digenea gen. sp.1 & -0.161 & 0.395 & -0.369 & 0.044 & -0.505 & 0.004 & -0.307 & 0.077 & -0.375 & 0.029 & -0.126 & 0.476 \\
\hline Digenea gen. sp. 2 & - & - & - & - & - & - & -0.119 & 0.501 & -0.193 & 0.273 & -0.162 & 0.358 \\
\hline $\begin{array}{l}\text { Phyllodistomum } \\
\text { spatula }\end{array}$ & -0.044 & 0.818 & 0.129 & 0.496 & 0.184 & 0.329 & - & - & - & - & - & - \\
\hline $\begin{array}{l}\text { Procamallanus (S.) } \\
\text { inopinatus }\end{array}$ & -0.387 & 0.034 & -0.221 & 0.240 & 0.315 & 0.089 & 0.448 & 0.008 & 0.358 & 0.037 & -0.022 & 0.9 \\
\hline $\begin{array}{l}\text { Rhabdochona } \\
\text { acuminata }\end{array}$ & - & - & - & - & - & - & 0.015 & 0.933 & 0.094 & 0.594 & -0.043 & 0.808 \\
\hline Contracaecum sp. & 0.130 & 0.492 & 0.035 & 0.854 & -0.129 & 0.494 & 0.164 & 0.353 & 0.097 & 0.583 & 0.100 & 0.572 \\
\hline Ergasilus sp. & - & - & - & - & - & - & 0.374 & 0.029 & 0.301 & 0.083 & -0.045 & 0.799 \\
\hline Acarina gen. sp & -0.334 & 0.071 & -0.478 & 0.007 & -0.194 & 0.303 & 0.016 & 0.928 & -0.087 & 0.624 & -0.214 & 0.223 \\
\hline
\end{tabular}

$P=p$-values

\section{Discussion}

Parasite communities in sympatric hosts with similar ecology and which are phylogenetically related tend to be structured in a similar manner (Muñoz et al., 2006; Oliveira et al., 2016; Hoshino et al., 2016; Santos-Bustos et al., 2018), especially when the diets of these hosts overlap in the environment. The similar component communities of $T$. angulatus and $T$. auritus parasites from the lower Rio Jari was composed of Monogenea, Digenea, Nematoda, Crustacea and Acarina, with a predominance of $A$. furculus and A. pithophallus monogeneans, parasites with simple, direct life cycles (Kohn et al., 2016). ANOSIM revealed that the abundance of parasites was similar in T. angulatus and 


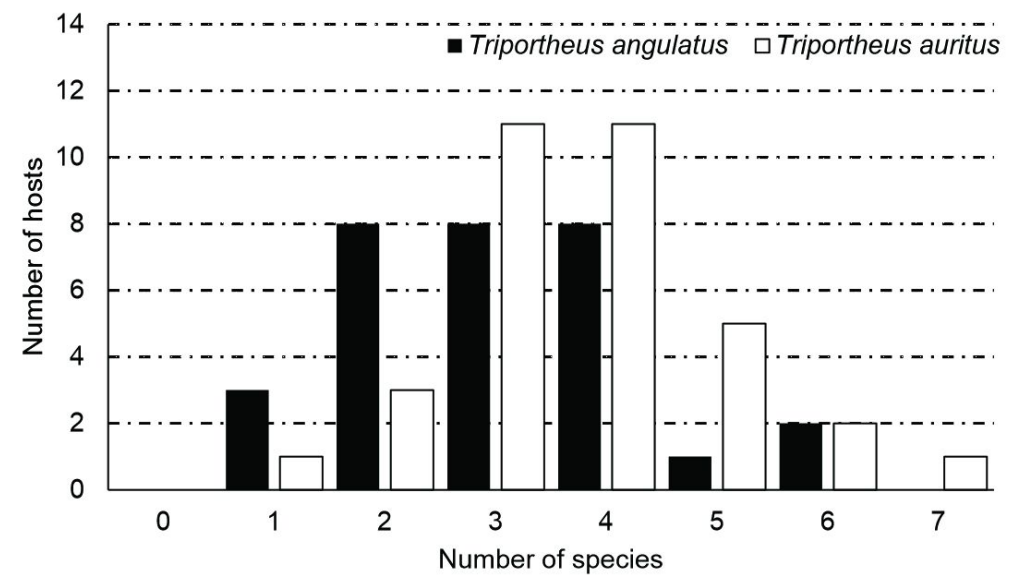

Figure 2. Species richness of parasites in Triportheus angulatus and Triportheus auritus from lower Jari River, in Brazilian Amazon.
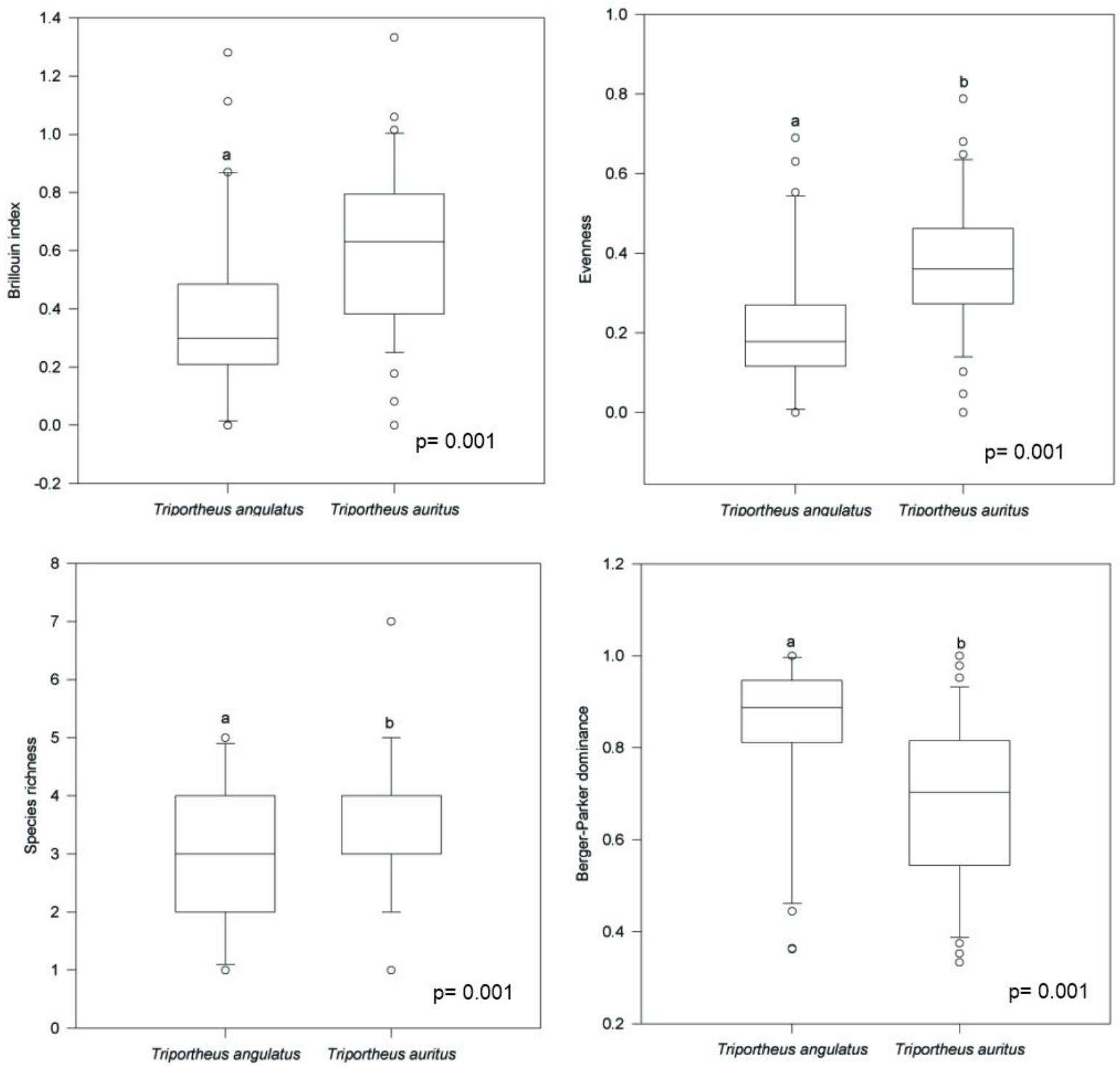

Figure 3. Descriptors of diversity for communities of parasites in Triportheus angulatus and Triportheus auritus from lower Jari River, in Brazilian Amazon (Box plots represent medians, interquartile ranges (25-75\%), minimum-maximum ranges and outliers). Different letters indicate differences between descriptor parameters. 


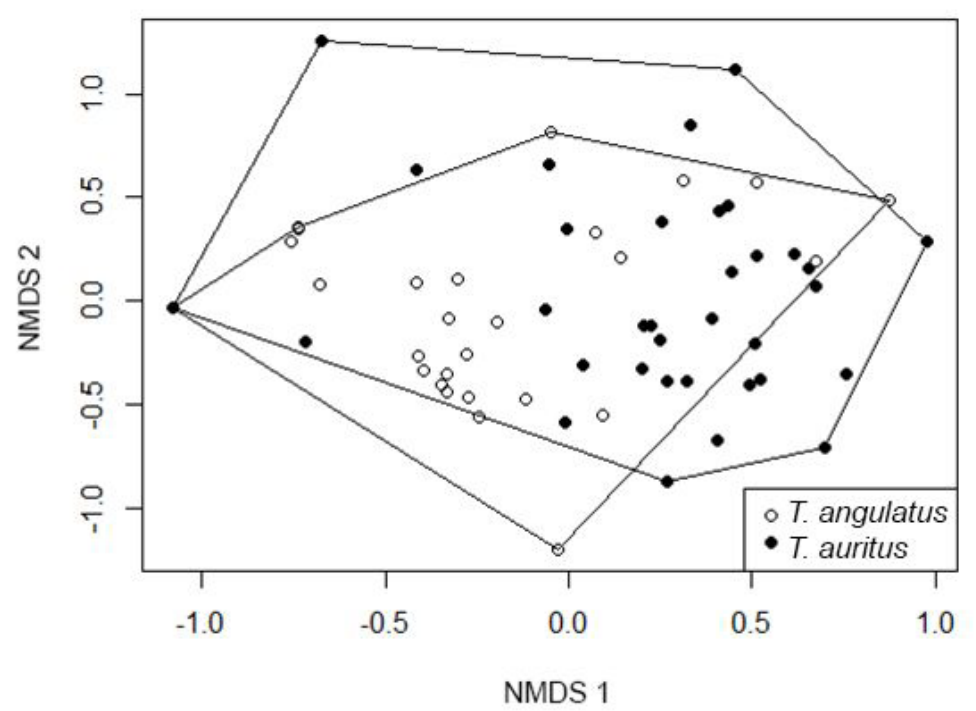

Figure 4. Non-metric multidimensional scaling ordination (NMDS) of abundance of parasites in Triportheus angulatus and Triportheus auritus from lower Jari River, in Brazilian Amazon.

T. auritus, as both hosts had a qualitative similarity of 78\%. The NMDS analysis revealed a slight difference between the parasite community of $T$. angulatus and $T$. auritus, caused by the abundance of $A$. furculus, A. pithophallus and $R$. acuminata. This can occur due to parasite abundance, which can vary depending on the birth rate and mortality, ability to migrate between hosts, competition, or detachment from the host by mechanical action and/or the physiological responses of the host (Anderson \& Gordon, 1982; Von Zuben, 1997; Luque et al., 2013).

In wild fish populations, quantitative and qualitative descriptive patterns are found among parasite communities (Magurran, 2004; Oliveira et al., 2016; Hoshino et al., 2016). In T. angulatus and T. auritus from the lower Rio Jari, we observed that the ecto and endoparasite communities were similar. However, the diversity and richness of parasite species were higher in T. auritus. The prevalence of R. acuminata was higher in $T$. auritus than in $T$. angulatus. The prevalence and abundance of Ergasilus sp. were higher in T. auritus. In addition, P. spatula occurred only in $T$. angulatus, while C. marginatum occurred only in $T$. auritus. Such differences may be related to the different contacts of these hosts with the infectious forms of the parasites in the environment, possibly associated with food, as fish need to explore different locations to feed, thus increasing the possibility of parasitic infection (Luque et al., 2004; Santos-Bustos et al., 2018).

In T. angulatus and T. auritus, infection by A. furculus and A. pithophallus, R. acuminata, Ergasilus sp. and Acarina gen. sp. presented aggregate dispersion. However, Digenea gen. sp.1 and Digenea gen. sp.2, P. spatula, P. (S.) inopinatus and Contracaecum sp. showed random dispersion. The aggregate dispersion pattern is common in fish populations and is caused by several factors associated with the host and the environment (Rohde et al., 1995; Neves et al., 2013; Oliveira et al., 2016; Hoshino et al., 2016). Random dispersion has generally been attributed to those species of pathogenic parasites which have little opportunity to colonize hosts (Guidelli et al., 2003).

In wild fish populations, the body size of hosts has been identified as a significant predictor of parasite burden (Poulin, 2004; Poulin \& Leung, 2011; Paraguassú \& Luque, 2007; Baia et al., 2018). Several studies on fish populations have shown that the abundance of parasites increases or decreases according to the age or size of the host fish (Poulin, 2004; Paraguassú \& Luque, 2007; Gonçalves et al., 2018; Baia et al., 2018). However, any correlation between the body size of the fish and the burden of the parasites using it as an intermediate host should be positive, as large hosts are unlikely to serve as prey. In $T$. angulatus, the abundance of $A$. furculus, Ergasilus sp., A. pithophallus and P. (S.) inopinatus correlated negatively with the length of the hosts. The abundance of Digenea gen. sp.1 and Acarina gen. sp. correlated negatively with body weight. However, the abundance of A. furculus, A. pithophallus and $P$. (S.) inopinatus in T. auritus correlated positively with the size of the hosts.

To conclude, we showed that the parasite community of $T$. angulatus and $T$. auritus were characterized by a low abundance of helminths, low species richness, low diversity and evenness, with a predominance of ectoparasite 
species. There was similarity between the metazoan parasite community of $T$. angulatus and $T$. auritus, but with differences in a few infracommunities, diversity and richness of parasites. Moreover, host size was a factor that influenced the diversity and species richness of parasites. Triportheus angulatus and $T$. auritus are intermediate hosts for metacercariae of the digeneas and larvae of Contracaecum sp., and definitive hosts for $P$. (S.) inopinatus and $R$. acuminata. This was the first study on parasites of $T$. auritus and $T$. angulatus from the Jari River.

\section{Acknowledgements}

We would like to thank Mr. João Pena de Oliveira for his assistance in collecting the fish. This study received financial support from the National Council for Scientific and Technological Development (Conselho Nacional de Desenvolvimento Científico e Tecnológico, CNPq) through a productivity grant to Tavares-Dias, M (Process number 303013/2015-0) and, Coordination for the Improvement of Higher Education Personnel (Coordenação de Aperfeiçoamento de Pessoal de Nível Superior, CAPES, Brazil) under the financial code 001, PROAP/CAPES resource, and granting the doctoral scholarship to Oliveira, MSB (Process number 88882.430002/2019-01) and Borges, WF (Process number 88887.484708/2020-00).

\section{References}

Abreu CHM, Cunha AC. Qualidade da água em ecossistemas aquáticos tropicais sob impactos ambientais no baixo Rio Jari-AP: revisão descritiva. Biota Amazôn 2015; 5(2): 119-131. http://dx.doi.org/10.18561/2179-5746/biotaamazonia.v5n2p119-131.

Almeida RG. Biologia alimentar de três espécies de Triportheus (Pisces: Characoideil, Characidae) do Lago do Castanho, Amazonas. Acta Amazon 1984; 14(1-2): 48-76. http://dx.doi.org/10.1590/1809-43921984142076.

Anderson RM, Gordon DM. Processes influencing the distribution of parasite numbers within host populations with special emphasis on parasite-induced host mortalities. Parasitology 1982; 85(Pt 2): 373-398. http://dx.doi.org/10.1017/S0031182000055347. PMid:7145478.

Araújo AS, Lima LTB, Nascimento WS, Yamamoto ME, Chellappa S. Características morfométricas-merísticas e aspectos reprodutivos da sardinha de água doce, Triportheus angulatus (Osteichthyes: Characiformes) do Rio Acauã do bioma Caatinga. Biota Amaz 2012; 2(1): 59-73. http://dx.doi.org/10.18561/2179-5746/biotaamazonia.v2n1p59-73.

Baia RRJ, Florentino AC, Silva LMA, Tavares-Dias M. Patterns of the parasite communities in a fish assemblage of a river in the Brazilian Amazon region. Acta Parasitol 2018; 63(2): 304-316. http://dx.doi.org/10.1515/ap-2018-0035. PMid:29654690.

Bush AO, Lafferty KD, Lotz JM, Shostak W. Parasitology meets ecology on its own terms: margolis et al. revisited.J Parasitol 1997; 83(4): 575-583. http://dx.doi.org/10.2307/3284227. PMid:9267395.

Cunha AC, Cunha HFA. Rede de meteorologia e recursos hídricos do Estado do Amapá (REMETAP): principais resultados. Tempo, clima e recursos hídricos: resultados do Projeto REMETAP no estado do Amapá. Macapá: IEPA; 2010.

Eiras JC, Takemoto RM, Pavanelli GC. Métodos de estudo e técnicas laboratoriais em parasitologia de peixes. Maringá: Eduem; 2006.

Empresa de Pesquisa Energética - EPE. Inventário hidroenergético da bacia hidrografica. Relatório final volume 8/9 - Apêndice D estudos socioambientais Tomo 1/4. Rio Jari: EPE; 2010.

Froese R, Pauly D. FishBase [online]. 2021 [cited 2021 Apr 15]. Available from: www.fish base.org/

Gonçalves BB, Oliveira MSB, Borges WF, Santos GG, Tavares-Dias M. Diversity of metazoan parasites in Colossoma macropomum (Serrasalmidae) from the lower Jari River, a tributary of the Amazonas River in Brazil. Acta Amazon 2018; 48(3): 211-216. http:// dx.doi.org/10.1590/1809-4392201704371.

Goulding M, Venticinque E, Ribeiro MLB, Barthem RB, Leite RG, Forsberg B, et al. Ecosystem- based management of Amazon fisheries and wetlands. Fish Fish 2018; 20(1): 138-158. http://dx.doi.org/10.1111/faf.12328.

Guidelli GM, Isaac A, Takemoto RM, Pavanelli GC. Endoparasite infracommunities of Hemisorubim platyrhynchos (Valenciennes, 1840) (Pisces: Pimelodidae) of the Baía River, upper Paraná River floodplain, Brazil: specific composition and ecological aspects. Braz J Biol 2003; 63(2): 261-268. http://dx.doi.org/10.1590/S1519-69842003000200011. PMid:14509848.

Hoshino MDFG, Neves LR, Tavares-Dias M. Parasite communities of the predatory fish, Acestrorhynchus falcatus and Acestrorhynchus falcirostris, living in sympatry in Brazilian Amazon. Rev Bras Parasitol Vet 2016; 25(2): 207-216. http://dx.doi.org/10.1590/S198429612016038. PMid:27334822.

Kohn A, Justo MCN, Cohen SC. Monogenoidea. In: Eiras JC, Velloso AL, Pereira J Jr, editors. Parasitos de peixes marinhos da América do Sul. Rio Grande: Ed. Furg; 2016. p. 53-94. 
Lasso CA, Sánchez-Duarte P. Los peces del delta del Orinoco: diversidad, bioecología, uso y conservación. Caracas: Chevron; 2011. Le Cren ED. The length-weight relationship and seasonal cycle in gonad weight and condition in the perch (Perca fluviatilis). J Anim Ecol 1951; 20(2): 201-219. http://dx.doi.org/10.2307/1540.

Lima FCT, Malabarba LR, Buckup PA, Silva JFP, Vari RP, Harold A, et al. Genera Incertae Sedis in Characidae. In: Reis RE, Kullander SE, Ferraris CJ Jr, editors. Check list of the freshwater fishes of South and Central America. Porto Alegre: Edipucrs; 2003. p. $106-169$. Ludwig JA, Reynolds JF. Statistical ecology: a primer on methods and computing. New York: Wiley-Interscience Pub; 1988.

Luque JL, Mouillot D, Poulin R. Parasite biodiversity and its determinants in coastal marine teleost fishes of Brazil. Parasitology 2004; 128(Pt 6): 671-682. http://dx.doi.org/10.1017/S0031182004005050. PMid:15206470.

Luque JL, Lacerda AC, Lizama MAP, Bellay S, Takemoto RM. In: Pavanelli GC, Takemoto RM, Eiras JC, editors. Parasitologia de peixes de água doce do Brasil. Maringá: Eduem; 2013. p. 67-84.

Magurran AE. Measuring biological diversity. Oxford (UK): Blackwell Science; 2004.

Malabarba MCSL. Revision of the Neotropical genus Triportheus Cope, 1872 (Characiformes: characidae). Neotrop Ichthyo/ 2004; 2(4): 167-204. http://dx.doi.org/10.1590/S1679-62252004000400001.

Moreira AC, Silva de Oliveira TT, Morey GAM, Malta JCO. Metazoários parasitas de Tripotheus angulatus (Spix \& Agassiz, 1829) do Lago Catalão, Rio Solimões, Amazonas, Brasil. Folia Amaz 2017; 26(1): 9-16. https://doi.org/10.24841/fa.v26i1.415.

Muñoz G, Grutter AS, Cribb TH. Endoparasite communities of five fish species (Labridae: Cheilininae) from Lizard Island: how important is the ecology and phylogeny of the hosts? Parasitology 2006; 132(3): 363-374. https://doi.org/10.1017/ S0031182005009133.

Neves LR, Pereira FB, Tavares-Dias M, Luque JL. Seasonal influence on the parasite fauna of a wild population of Astronotus ocellatus (Perciformes: Cichlidae) from the Brazilian Amazon.J Parasito/ 2013; 99(4): 718-721. http://dx.doi.org/10.1645/12-84.1. PMid:23421456.

Oliveira MSB, Gonçalves RA, Tavares-Dias M. Community of parasites in Triportheus curtus and Triportheus angulatus (Characidae) from a tributary of the Amazon River system (Brazil). Stud Neotrop Fauna Environ 2016; 51(1): 29-36. https://doi.org/10.1080/01 650521.2016 .1150095 .

Paraguassú AR, Luque JL. Metazoários parasitos de seis espécies de peixes do reservatório de Lajes, Estado do Rio de Janeiro, Brasil. Braz J Vet Parasit 2007; 16(3): 121-128. https://doi.org/10.1590/S1984-29612007000300002.

Ponte SC, Ferreira LC, Bittencourt SCS, Queiroz HL, Zacardi DM. Variação espacial e temporal das larvas de Triportheus (Characiformes, Triportheidae), no médio Rio Solimões, Amazônia Central, Brasil. Act Fish Aquat Res 2016; 4(2): 71-81. https:// doi.org/10.2312/Actafish.2016.4.2.71-81.

Poulin R, Leung TLF. Body size, trophic level, and the use of fish as transmission routes by parasites. Oecologia 2011; 166: 731738. https://doi.org/10.1007/s00442-011-1906-3.

Poulin R. Macroecological patterns of species richness in parasite assemblages. Basic Appl Ecol 2004; 5(5): 423-434. http://dx.doi. org/10.1016/j.baae.2004.08.003.

R Core Team. A language and environment for statistical computing [online]. Vienna, Áustria: R Foundation for Statistical Computing; 2020 [cited 2021 Feb 15]. Available from: http://www.R-project.org/

Rohde K, Hayward C, Heap M. Aspects of the ecology of metazoan ectoparasites of marine fishes. Int J Parasitol 1995; 25(8): 945-970. http://dx.doi.org/10.1016/0020-7519(95)00015-T. PMid:8550295.

Rojas WT, Betancourt CAR, Rengifo OR. Análisis del contenido estomacal y la ecología trófica de la Triportheus auritus (Jolombo). Rev Electrón Vet 2016; 17(11): 1-9.

Rózsa L, Reiczigel J, Majoros G. Quantifying parasites in samples of hosts. J Parasitol 2000; 86(2): 228-232. http://dx.doi. org/10.1645/0022-3395(2000)086[0228:QPISOH]2.0.CO;2. PMid:10780537.

Santos GD, Jegu M, Merona BD. Catálogo de peixes comerciais do baixo Rio Tocantins. Manaus: Eletronorte/CNPq/INPA; 1984.

Santos-Bustos NG, Violante-González J, Monks S, Rojas-Herrera AA, García-lbáñez S, Flores-Rodríguez P, et al. Species richness and similarity of metazoan parasite communities in three species of leatherjacket (Oligoplites: Pisces: Carangidae) from the Pacific coast of Mexico. Invertebr Biol 2018; 137(3): 205-220. http://dx.doi.org/10.1111/ivb.12220.

Sá-Oliveira JC, Angelini R, Isaac-Nahum VJ. Diet and niche breadth and overlap in fish communities within the area affected by an Amazonian reservoir (Amapá, Brazil). An Acad Bras Cienc 2014; 86(1): 383-405. http://dx.doi.org/10.1590/0001-3765201420130053. PMid:24676175.

Soares MGM, Costa EL, Siqueira-Souza FK, Anjos HDB, Yamamoto KC, Freitas CEC. Peixes de lagos do médio Rio Solimões. 2nd ed. Manaus: Instituto Piatam; 2011. 
Parasites in Triportheus spp.

Tavares-Dias M, Sousa TJSM, Neves LR. Parasitic infections in two benthopelagic fish from Amazon: The arowana Osteoglossum bicirrhosum (Osteoglossidae) and oscar Astronotus ocellatus (Cichlidae). Biosci J 2014; 30: 546-555.

Von Zuben CJ. Implications of spatial aggregation of parasites for the population dynamics in host-parasite interaction. Rev Saude Publica 1997; 31(5): 523-530. http://dx.doi.org/10.1590/S0034-89101997000600014. PMid:9629733.

Yamamoto KC, Soares MGM, Freitas CEC. Alimentação de Triportheus angulatus (Spix \& Agassiz, 1829) no Lago Camaleão, Manaus, AM, Brasil. Acta Amazon 2004; 34(4): 653-659. http://dx.doi.org/10.1590/S0044-59672004000400017.

Zar JH. Biostatistical analysis. 5th ed. Upper Saddle River (NJ): Prentice Hall; 2010. 